酒井寛二 [(株)大林組技術研究所 室長・工博 $]$

床吹き出し空調方式は, 情報化が進んだ執務空間を中心に, 試行 錯誤で適用例が増加しつつあり, 理論的な設計手法の解明は多少遅 れている傾向が感じられていた。それだけに本報文の内容, 特に床 下空間の高さを最小限にしようとする探求姿勢には大いに共感する ところがあり, 研究結果が大いに期待された。しかしながら本報文 のみでは, 後述するように設計の基礎資料とするには情報量が不足 しており, 今後のさらなる研究展開と, その成果の公開が待たれる ところである。

まず本研究における実測は, 床下空間の風向, 風速そして静圧分 布に限定されている。しかし実際に最終的に必要な情報は，床面の 吹き出し口からの風量である。静圧と風量との関係は, 広い空間に 配置された渦無し気流のもとでは一元的であるが，今回の実験のよ うに, 吹き出し口は上流側流路寸法（床下高さ）に比較してかなり 大きく, また床下では渦が発生し, さらに吹き出し口にダンパも組 み合わされている場合には, 我々の類似実験結果では, 近傍の一点 の静圧と吹き出し風量とは, それほどきれいな一元的関係に無い。 よって別途, 類似条件下での静圧と流量の関係を求めておかない
と，風量の均一性評価は出来ず，この点からのさらなる解明を期待 したい。

床下の障害物による風速，静圧分布の変化は非常に興味が持たれ た。しかしこの記述においても，前半は流路の障害物閉鎖率で定量 的に表示し, 後半は F ケーブル 15 本追加と定性的な表現に止まっ ている。ケーブルをどのように配置し，平均的閉鎖率がいなほどだ つた場合かの記述がないので，模型実験と導入実験施設との対比が 不可能で, 実用上の価值が減少しているのが残念である。また実験 例で障害物前後に大きな静圧差があり, 床下配線がどんどん増加し ていく現状を見ると，「おわりに」に示すように，低床式 OA フロ アで空調可能との単純な結論はむずかしくはなかろうか。そして障 害物の定量的な影響把握をしたうえで, 技術報告文書として公表し てくれれば，読者にとって有用な情報として役に立ったと思われ， 今後のさらなる展開に期待したい。

最後に本質的事項ではないが, 図-10 と 11 において, 給気ダク ト1の位置は，風速や静圧分布からみて誤記ではないかと思われ る。
近年オフィスビルでは，OA 機器の配線処理を目的に低床型 $\mathrm{OA}$ フロアが普及している。この OA フロア内を加圧チャンバとして 利用することは, アンダーフロア空調システムの低コスト化に有効 と考えられる。このような背景から，本技術報告は低床型 OA フ ロアによる二重床内気流分布に関し，模型および実物での実験を行 い, 問題点の把握，その対応策についてまとめたものであり，今 後, 低床型 $\mathrm{OA}$ フロアを用いたアンダーフロア空調システムの普 及を図る上で有効なものと考えられる。

\section{1. 縮尺模型実験での検討}

本報告では，1/5の縮尺模型を用い，二重床内静圧のばらつきに 関し，1)空気導入方法，2)床高さ，3)障害物の高さ，4)ガイドべ ーンの効果について検討している。その結果, 二重床内静圧のばら つきを小さくする方法として 1)空気の導入を全面から行うこと， 2)床高さを大きくすること，3）二重床内の障害物は低い方が良い こと，4)床高さや空気導入口に制限がある場合, 空気導入口にガ イドベーンを設けることが有効なことを示している。二重床内静圧 のばらつきは, 上記のパラメータの他に奥行き, 幅, 二重床内通気 抵抗などにより変化することが予想され，各パラメータと二重床内 静圧のばらつきの程度を定量的に把握できれば，さらに有効な結果
になるものと考えられる。また，ガイドベーンの形状も二重床内静 圧のばらつきを左右する要素と考えられ，具体的な形状，寸法の情 報は実際の設計にとって貴重なデータと考えられる。なお，縮尺模 型の実験では相似則の確認が必要となるが，本報告ではこの点の記 述が欲しいところである。

2. 実大オフィスでの検討

床高さ $60[\mathrm{~mm}]$ (有効高さ $34[\mathrm{~mm}]$ ) の実オフィスを用い, 1)空気導入口配置，2)二重床内障害物をパラメータに二重床内気 流特性の検討を行い, 二重床内静圧のばらつきを小さくするには, 1) 空気導入口の数を多くすること，2)障害物の前後で圧力損失が 生ずることを示している。本実験結果は, 極めて床高さの小さな OA フロアを用いてアンダーフロア空調システムを実現した点で評 価できる。しかし，実際に導入された空調システムの評価は，室内 温度分布で評価されることが多く, 本実験においても室温分布が適 正な範囲にあることを示して欲しかった。また，二重床内の導入口 での圧力損失は送風機の容量決定, 運転費に大きな影響を与えるこ とから，二重床内の導入口の形状と圧力損失の関係が定量的に示さ れていれば, 設計上貴重なデータになると考えられる。今後の進展 を期待したい。 